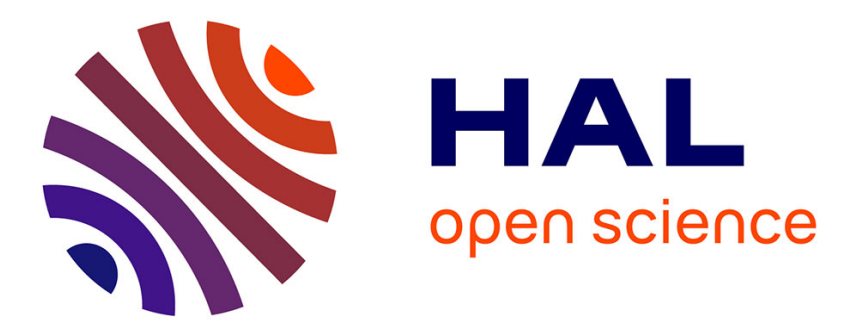

\title{
Late Carnian (Tuvalian, Tropites dilleri zone) ostracods (Crustacea) from the Mufara Formation (Monte Scalpello, Central-Eastern Sicily, Italy) \\ Sylvie Crasquin, Francesco Sciuto, Agatino Reitano
}

\section{- To cite this version:}

Sylvie Crasquin, Francesco Sciuto, Agatino Reitano. Late Carnian (Tuvalian, Tropites dilleri zone) ostracods (Crustacea) from the Mufara Formation (Monte Scalpello, Central-Eastern Sicily, Italy). Annales de Paléontologie, 2018, 104 (2), pp.129-142. 10.1016/j.annpal.2018.03.001 . hal-02108580v2

\section{HAL Id: hal-02108580 \\ https://hal.science/hal-02108580v2}

Submitted on 17 Dec 2020

HAL is a multi-disciplinary open access archive for the deposit and dissemination of scientific research documents, whether they are published or not. The documents may come from teaching and research institutions in France or abroad, or from public or private research centers.
L'archive ouverte pluridisciplinaire HAL, est destinée au dépôt et à la diffusion de documents scientifiques de niveau recherche, publiés ou non, émanant des établissements d'enseignement et de recherche français ou étrangers, des laboratoires publics ou privés. 
Formation (Monte Scalpello, Central-Eastern Sicily, Italy).

${ }^{1}$ Sylvie Crasquin CR2P - CNRS, MNHN, Sorbonne Université, 4 Place Jussieu, T. 46-56, E.5, F75252, Paris cedex 05, France. E-mail: sylvie.crasquin@ upmc.fr. ${ }^{2}$ Francesco Sciuto,

Palaeoecological Research Group, Department of Biological, Geological and Environmental Science, Catania University, Corso Italia, 55, Catania 95129, Italy. E-mail: fsciuto@ unict.it. Tel. +39957195769. ${ }^{3}$ Agatino Reitano, Natural History Museum, via degli Studi 9, 97013 Comiso (Ragusa), Italy. E-mail: tinohawk@ yahoo.it.

\section{Abstract}

Ostracod association from the Upper Triassic (Tropites dilleri zone of the Carnian stage) of the sedimentary succession (Mufara Formation) exposed along the east side of Monte Scalpello (Catenanuova, central eastern Sicily) have been studied for the first time. The specimens, silicified, are rare but well preserved and often consist of complete carapaces. They belonging to eight families: Healdiidae, Cavellinidae, Bairdiidae, Acratiidae, Bythocyprididae, Pontocyprididae, Judahellidae, Glorianellidae.

Twenty - three taxa have been listed; the family Bairdiidae is the most represented among all the others with fifteen species. Four species are new: Bairdia scaliae n. sp., Acratia maugerii n. sp., “Anchistrocheles”gemmellaroi n. sp. and Judahella? montanarii n. sp. Other species are left in open nomenclature because of the lack of specimens.

\section{Résumé}

L'association d'ostracodes de la succession sédimentaire du Trias supérieur (Carnien, Tropites dilleri zone, Mufara Formation) affleurant du côté oriental du Monte Scalpello (Catenanuova, Sicile centre-orientale) a été étudiée pour la première fois. Les spécimens, silicifiés, 
sont rares mais bien conservés et se composent souvent de carapaces complètes. Les espèces appartiennent à huit familles: Healdiidae, Cavellinidae, Bairdiidae, Acratiidae, Bythocyprididae,Pontocyprididae, Judahellidae, Glorianellidae. La famille Bairdiidae est la plus représentée avec quinze espèces sur les vingt-trois répertoriées. Quatre espèces sont nouvelles: Bairdia scaliai n. sp., Acratia maugerii n. sp., “Anchistrocheles” gemmellaroi n. sp. et Judahella? montanarii n. sp. D'autres espèces sont laissées en nomenclature ouverte.

Keywords: Ostracods: Late Triassic, Neo-Tethys, Central-Eastern Sicily, Mount Scalpello, Mufara Formation, palaeoenvironmental reconstruction, new species.

Mots-clefs: Ostracodes: Trias supérieur, Néotéthys, Sicile centre-orientale, Mont Scalpello, Formation Mufara, paléoenvironnement, nouvelles espèces.

\section{INTRODUCTION}

After the first studies on Mesozoic sediments cropping out in the Monte Scalpello area carried out since the early 19th century (Calcara, 1840, 1845; Nelli, 1899a, b; Marinelli, 1899; Gemmellaro, 1860, 1904), the Upper Triassic fauna of "Clay-calcareous-arenaceous alternation" ("Flysch Carnico" Auct.), best referring to the "Mufara Formation" (Schmidt di Friedberg and Trovò, 1962) of the "Monte Judica Group" (Scalia, 1909) have been the subject of numerous palaeontological detailed studies on invertebrates: the molluscs have been studied by Scalia (1907, 1909, 1910, 1912, 1914), the cnidaria by Maugeri Patanè (1934), the ammonites by Lentini (1974), the foraminifers, chaetetids, sphinctozoans and other organisms by Carrillat and Martini (2009).

So far, ostracods (Crustacea) coming from the Mufara Formation in the Monte Scalpello area never have been studied; the only references to these organisms are found in Lentini (1974) which refers about a high level of the Mufara Formation rich in Bairdiidae and in Carrillat and Martini (2009) which cite, only the presence of this organisms.

The present paper, therefore, wants to be a first contribution to the knowledge of the ostracod fauna of the Mufara Formation clays outcropping in the Monte Scalpello area. 
Furthermore, this analysis is an important step in the knowledge of the recovery of ostracod fauna after the Permian - Triassic massive extinction. The data on Middle and early Late Triassic are rare.

\section{MATERIALS AND METHODS}

Monte Scalpello is located (Fig. 1) in central eastern Sicily in the right side of Dittaino River

Fig. 1. Geographical location of the sampling area. Localisation géographique de la zone d'étude.

to the south east of the town of Catenanuova (EN), $40 \mathrm{Km}$ west of Catania (F 633 IV NO of the Carta d'Italia alla scala 1:25.000). It is inserted, as part of the "Monte Judica Units" (Lentini, et al., 1987), along the northern margin of the Gela Foredeep, in the geodynamic context (Fig. 2) of the southern end of Fig. 2. Structural scheme of the central Mediterranean area with the location of the study area (after Grasso, 2001 modified). Schéma structural de la Méditerranée centrale avec la localisation de la zone d'étude (d'après Grasso, 2001 modifié).

$$
\text { the Maghrebian - Sicilian-Southern Apennine nappes and as such, it would dwarf the mildly }
$$
folded foreland (Hyblean Plateau) (Lentini et al., 1987; Grasso, 2001 inter alias).

The Monte Scalpello area is lithologically characterized by a Mesozoic-Cainozoic sediments complex belonging to the so-called Imerese Succession (Lentini et al., 1987; Montanari, 1987; inter alias) or Imerese-Sicano Succession (Carrillat and Martini, 2009; Di Paolo et al., 2012). This sedimentary succession settled inside the pelagic Imerese Basin which had formed during the MesoCenozoic extensional phases and which was delimited by the Panormide Carbonate Platform to the west and the Trapanese Carbonate Platform to the east and to the south (Fig. 3) (Catalano and D’Argenio, 1982; Montanari, 1987; Speranza and Minelli, 2014). 
Fig. 3. Schematic palaeogeographic reconstruction of Pangaea and Neo-Tethys in Late Triassic times (after Speranza \& Minelli (2014), Golonka, 2007 and Preto et al., 2010 modified). Reconstruction paléogéographique schématique de la Pangée et de la Néo-Téthys à la fin du Trias (d'après Speranza \& Minelli, 2014; Golonka, 2007 et Preto et al., 2010 modifié).

The Imerese Basin, therefore, is represented by the transitional pelagic facies between the Panormide and Trapanese shelf facies, on the one hand, and the bathyal facies of the Neo-Tethys, on the other (Fig. 3).

The Imerese succession of Monte Scalpello (Fig. 4) starts with the "Carnian Flysh" (Auctorum) or, according to Schmidt di Friedberg and Trovò (1962), the Mufara Formation. This unit, outcropping in the southern slopes of the mount, is prevalently constituted by dark grey clays rich in ammonites with rare interbedded levels of fossiliferous calcarenites and fibrous calcite with Halobia spp. imprints.

Fig. 4. Geological map of the Monte Scalpello area (after Lentini, 1974 and Di Paolo et al. 2012, modified). Carte géologique de la région de Monte Scalpello (d'après Lentini, 1974 and Di Paolo et al. 2012, modifié).

The detailed stratigraphic attribution of Mufara Formation has been the subject of different opinions since the beginning of the twentieth century; Calcara, 1841, 1845; Nelli (1899a, b), Gemmellaro (1904), Scalia (1907; 1909; 1910 - 1914), Maugeri Patanè (1934), Lentini (1974) and Dal Sasso et al. (2014) assigned these sediments to the Late Triassic (Carnian).

\footnotetext{
Fig. 5. Carnian Ammonoid zones. (After Lucas, 2010). Zones à Ammonoïdés du Carnien (d'après Lucas,
} 2010)

Lentini (1974), on the basis of the ammonites fauna found, attributes the lowest levels of Monte Scalpello section, to the Trachyceras aonoides ammonite zone of the Early Carnian; 
nevertheless the presence of Tropitidae among the specimens coming out from this levels, excludes that this formation belongs to the Early Carnian (Lucas, 2010; Jenks et al., 2015).

The subsequent sedimentary layers are attributed, again by Lentini (1974), to the Tropites subbullatus zone; nevertheless the contemporary presence of specimens of Trachyceratidae (?Neoprotrachyceras, Trachysagenites, Pamphagosirenites) found by the authors of the present paper, and specimens of Tropitidae, suggests that both this fossiliferous horizons can be referred to the Tropites dilleri zone (Lucas, 2010; Jenks et al., 2015). A confirmation of this datum comes from Carrillat and Martini (2009) who, mostly on the basis of the foraminifers, refers the same clays of Mufara Formation outcropping at Monte Gambanera, nine kilometers to the south of the studied area, to the upper part of the Late Carnian (Tropites subbullatus/Anatropites spinosus zones). According to Jenks et al. (2015) the base of Tuvalian Substage (upper part of the Carnian Stage) is characterized by the appearance and radiation of the Tropitidae. Therefore the presence of Tropitidae reported already by Gemmellaro (1904), Scalia (1909) and Lentini (1974) remove all doubts about the attribution of this sedimentary levels out cropping, to the Tuvalian substage (Late Carnian, Tropites dilleri zone) (Fig. 5).

Over the Mufara Formation follow conformably the Upper Triassic cherty limestone with Halobia, the Jurassic - Cretaceous radiolarian cherts and unconformably the Eocene - Oligocene limestone ("Scaglia"). The stratigraphic sequence is finally closed by Oligocene - Miocene clays and glauconitic sandstones.

For the present work twenty kilograms of sediments were collected from one stratigraphic level of the Mufara Formation cropping out in contrada Paraspora, two hundred meters southwest of Masseria Mannino (37³2'56.86' N; 1440’30.64'’E) along the east side of Monte Scalpello, (Figs. 1, 4). Sediments were routinely washed, dried in oven and sieved. Then, ostracod specimens were picked out from the $>63 \mu \mathrm{m}$ fraction. The ostracod specimens were examined and measured under a stereomicroscope, then photographed under an LMU Tescan Vega II SEM. The material is housed in the Palaeontological Museum of the University of Catania. The repository number of the 
holotypes and the paratypes are given in the systematic descriptions.

133

134

135

136

137

138

139

140

141

142

143

144

145

146

147

148

149

150

151

\section{RESULTS}

The sample taken results to be constituted mostly by pelitic sediments, indeed almost the entire sediment is passed over the $63 \mu \mathrm{m}$ sieve. The poor washing residue (about 100 grams) provided in order of abundance, gastropods, brachiopods, bivalves and crinoids, echinoids skeletal fragments and small size ammonites. Microfauna is very poor in foraminifers represented prevalently by the genera Glomospira and Hemidiscus; ostracods, the majority of which is constituted by juvenile forms, are relatively abundant.

\section{Systematic palaeontology}

Ostracods from a sample of clay of the Mufara Formation taken at the base of Monte

Scalpello are systematically listed. The specimens belong to the Order Metacopida Sylvester-

Bradley, 1961 and Podocopida Sars, 1866, and eight families Healdiidae Harlton, 1933,

Cavellinidae Egorov, 1950, Bairdiidae Sars, 1866, Acratiidae Gründel, 1962, Bythocyprididae

Maddocks, 1969, Pontocyprididae Müller, 1894, Judahellidae Sohn, 1968, Glorianellidae Snejder, 1960.

Abbreviations. L: length; H: height; T: thickness; RV: right valve; LV: left valve; DB:

dorsal border; VB: ventral border; AB: anterior border; PB: posterior border; PVB: postero-ventral border; AVB: antero-ventral border; PDB: postero-dorsal border; PVB: postero-ventral border.

Class Ostracoda Latreille, 1806

Order Metacopida Sylvester-Bradley, 1961

Suborder Metacopina Sylvester-Bradley, 1961 
Superfamily Healdioidea Harlton, 1933

Family Healdiidae Harlton, 1933

Genus Ogmoconchella Gründel, 1964 emend Michelsen, 1975

Type species: Healdia aspinifera Drexler, 1958

\section{Ogmoconchella felsooersensis (Kozur, 1970)}

Fig. $6 \mathrm{a}-\mathrm{b}$

1970 Healdia (Healdia) felsooersensis n. sp. - Kozur, p. 409, pl. 3, fig. 13, pl.4, figs; 1 - 6 1995 “Hungarella” felsooersensis (Kozur, 1970) - Monostori, p. 40 - 41, pl. 1, figs. 2 - 4 1996 Healdia (Healdia) felsoorensis Kozur, 1970 - Crasquin-Soleau and Gradinaru, pl. 9,

fig. 14

2013 Healdia (Healdia) felsooersensis Kozur, 1970 - Sebe et al., pl. 4, fig. 14

2013 Hungarella problematica (Méhes, 1911) - Monostori and Toth, p. 308, Pl. 4, Figs. 14 17

Material: 2 complete carapaces.

Dimensions (figured specimen): $\mathrm{L}=790-810 \mu \mathrm{m} ; \mathrm{H}=580 \mu \mathrm{m} ; \mathrm{T}=380 \mu \mathrm{m}$.

Stratigraphic and geographic range: Early Anisian of Felsőörs, Balaton Highland, Hungary (Kozur, 1970, Monostori, 1995), Early Anisian of Dobrogea, Romania (Sebe et al., 2013), Late Carnian (Tropites dilleri zone), Mufara Formation outcropping in the east side of Monte Scalpello (37³2’56.86’’N; 1440’30.64’’E), Sicily, Italy (this work).

Remarks: A great confusion exists in the systematics of Late Permian - Triassic Healdiidae genera Hungarella-Ogmoconcha-Ogmochonchella.

Some authors consider Hungarella Méhes, 1911 (which has not type material-Monostori, 1995, p. 40) and Ogmoconcha Triebel, 1941 as synonyms (Moore, 1961; Anderson, 1964). Shaver (in Moore 1961) and Sohn (1968) don't agree with this synonymy. In fact the two genera are extremely 
close. The third genus Ogmoconchella was introduced by Gründel (1964) and emended later by Michelsen (1975) mainly on the presence of a spine at PVB. We use here this character to attribute the species felsooersensis to Ogmoconchella.

Genus Healdia Roundy, 1926

Type species Healdia simplex Roundy, 1926

\section{Healdia? sp.}

Fig. $6 \mathrm{c}-\mathrm{d}$

Material: 2 complete carapaces.

Dimensions: fig. $6 \mathrm{c}: \mathrm{L}=660 \mu \mathrm{m} ; \mathrm{H}=580 \mu \mathrm{m}$; fig. $6 \mathrm{~d}$ : $\mathrm{L}=680 \mu \mathrm{m}, \mathrm{T}=310 \mu \mathrm{m}$. Stratigraphic and geographic ranges: Late Carnian (Tropites dilleri zone), Mufara Formation outcropping in the east side of Monte Scalpello (37'32'56.86' 'N; $\left.14^{\circ} 40^{\prime} 30.64^{\prime \prime} \mathrm{E}\right)$, Sicily, Italy (this work).

Remarks: In right lateral view, the carapace has all the characteristics of the genus Healdia. However the dorsal view is very far from this genus. Indeed, here the carapace is biconvex with a maximum of thickness at mid-L (in Healdia genus the posterior part of the carapace is truncated) and here there is only one spine at RV (in Healdia genus spines are present at PVB of both valves) As far as the muscle scars cannot be observed, the figured specimens are dubiously attributed to the genus Healdia.

Superfamily Cavellinoidea Egorov, 1950

Family Cavellinidae Egorov, 1950

Genus Bektasia Özdikmen, 2010

Type species. Reubenella avnimelechi Sohn, 1968

\section{Bektasia sp.1}

Fig. 6 e

Material:1 carapace. 
Dimensions: $\mathrm{L}=662 \mu \mathrm{m} ; \mathrm{H}=420 \mu \mathrm{m}$

Stratigraphic and geographic range: Late Carnian (Tropites dilleri zone). Mufara Fm outcropping in the east side of Monte Scalpello (37³2'56.86'’N; 1440'30.64'’E), Sicily, Italy (this work).

Remarks: this specimen could be compared to Bektasia subcynlindrica (Sandberg, 1866) in Kristan-Tollmann, 1973 from the Carnian of North Italy (Kristan-Tollmann, 1973) which has a similar lateral outline but has a shorter ADB and deeper sulci.

Order Podocopida Sars, 1866

Suborder Bairdiocopina Gründel, 1967

Superfamily Bairdioidea Sars, 1866

Family Bairdiidae Sars, 1866

Genus Hiatobairdia Kristan-Tollmann, 1970

Type species Hiatobairdia subsymmetrica Kristan-Tollmann, 1970

Hiatobairdia subsymmetrica Kristan-Tollmann, 1970

Fig. $6 \mathrm{f}-\mathrm{h}$

1970 Hiatobairdia subsymmetrica n. gen. n. sp. - Kristan-Tollmann, p. 268, pl. 35, figs. 1 - 3.

1976 Hiatobairdia subsymmetrica Kristan-Tollmann, 1970 - Tollmann, 1976, p. 276, pl. 163, fig.

14.

1978 Hiatobairdia subsymmetrica deformis n. sp. - Kristan-Tollmann, p. 83, pl. 4, figs. 1 - 7

1979 Hiatobairdia subsymmetrica Kristan-Tollmann, 1970 - Kristan-Tollmann et al., p. 147, pl. 6, fig. 4.

Material: 3 complete carapaces.

Dimensions (specimen figured in fig. $6 \mathrm{f}$ ): $\mathrm{L}=1040 \mu \mathrm{m} ; \mathrm{H}=520 \mu \mathrm{m}$. 
234 Tollmann, 1976; 1978), Late Carnian (Tropites dilleri zone; this work), Rhaetian of Austrian Alps 235 (Kristan-Tollmann, 1970) and Central Iran (Kristan-Tollmann, 1979).

236 Remarks: the Triassic genus Hiatobairdia Kristan-Tollmann, 1970 and the Permian genus 237 Kempfina Crasquin, 2010 (in Crasquin et al., 2010) differ from other bairdiidae by the "acratian 238 beak" at AVB, and the two symmetric valves. The surface of the carapace is often punctuated. 239 Hiatobairdia subsymmetrica is characterized by its fine ridge underling the $\mathrm{VB}, \mathrm{a} \mathrm{H} / \mathrm{L}=0.53-$ $240 \quad 0.56$; the dorsal outline biconvex and the regularly punctuated carapace.

Remarks: The present specimens differ from Bairdia humilis Monostori, 1995 from Late 
260 Formation outcropping in the east side of Monte Scalpello (37³2'56.86' 'N; 1440'30.64' E),

261 Sicily, Italy (this work).

Remarks: the specimens are very close to Bairdia deformata Kollmann, 1963 from the

(1963).

266

Bairdia cassiana (Reuss, 1869)

2013 Bairdia cassiana (Reuss, 1868) - Monostori and Tóth, p. 310, pl. 2, figs. 7 - 8, 10

Material: 1 carapace

Dimensions: $\mathrm{L}=900 \mu \mathrm{m} ; \mathrm{H}=490 \mu \mathrm{m}$

Stratigraphic and geographicrange: Early Anisian of Dobrogea, Romania (Crasquin-

Soleau and Gradinaru, 1996); Late Anisian of Balaton Highland, Hungary (Monostori, 1995),

Ladinian of Balaton Highland (Monostori and Tóth, 2013), Early Carnian of Southern Alps, Italy

(Reuss, 1868, Gümbel, 1869, Ulrichs, 1970; Kristan-Tollmann, 1978), Late Carnian (Tropites 
dilleri zone); Mufara Formation outcropping in the east side of Monte Scalpello (37³2'56.86' 'N; $14^{\circ} 40^{\prime} 30.64 ’$ 'E), Sicily, Italy (this work)

\section{Bairdia sp. 1}

Fig. $6 \mathrm{n}-\mathrm{o}$

Material: 2 carapaces

Dimensions: $\mathrm{L}=830 \mu \mathrm{m} ; \mathrm{H}=480 \mu \mathrm{m}$

Stratigraphic and geographic range: Late Carnian (Tropites dilleri zone), Mufara

Formation of east side of Monte Scalpello (37³2'56.86’'N; 1440'30.64' 'E), Sicily, Italy (this work).

\section{Bairdia balatonica Méhes, 1911}

Fig. $6 \mathrm{p}$

1911 Bairdia balatonica n. sp. - Méhes, p. 13 - 14, pl. 1, figs. 8 - 11

1911Bairdia badayi n. sp. - Méhes, p. 17 - 18, pl. 1, figs. 29 - 30

?1965Bairdia balatonica Méhes var. 1911 - Széles, p. 414, fig. 4

1965 Bairdia dadayi Méhes, 1911 - Széles, p. 412 - 413, fig. 1

1978 Bairdia cf. balatonica Méhes - Kristan-Tollmann, p. 81, pl. 1, figs. 1 - 3

1995Bairdia balatonica Méhes, 1911 - Monostori, p. 42, pl. 2, fig. 1 (non figs. 2 and 3)

2011 Bairdia balatonica Méhes, 1911 - Forel and Crasquin, p. 252, fig. 5 A

2013 Bairdia balatonica Méhes, 1911 - Monostori and Tóth, p. 309, figs. 1 - 5

Material: 1 carapace

Dimensions: $\mathrm{L}=860 \mu \mathrm{m} ; \mathrm{H}=545 \mu \mathrm{m}$

Stratigraphic and geographic range: Spathian - Anisian of South Tibet (Forel and

Crasquin, 2011), Anisian (Monostori, 1995), Ladinian (Monostori and Tóth, 2013) and Early 
Carnian (Méhes, 1911; Széles, 1965;) of Hungary, Early Carnian of Southern Alps, Italy (Kristan-

Tollmann, 1978), Late Carnian (Tropites dilleri zone). Mufara Formation outcropping in the east side of Monte Scalpello (37³2'56.86’’N; 1440’30.64'’E), Sicily, Italy (this work)

\section{Bairdia scaliai n.sp.}

Fig. $6 \mathrm{q}-\mathrm{r}$

Etymology: The species is named in memory of Salvatore Scalia (1874-1923),

palaeontologist at Catania University, for his scientific engagement in the Mesozoic fauna of Monte Scalpello.

Material: four complete carapaces.

Holotype: complete carapace figured in Fig. 6 r (PMC. O 17 H 11/4/2017), dimensions: L = $740 \mu \mathrm{m} ; \mathrm{H}=445 \mu \mathrm{m}$

Paratype: complete carapace figured in Figure 5 q (PMC. O 65-67 P 10/4/2017).

Type locality: East side of Monte Scalpello (37³2’56.86’’N; 1440’30.64’’E), Catenanuova, Sicily, Italy

Type horizon: Late Carnian (Tropites dilleri zone) in the dark grey clays of the Mufara Formation.

Diagnosis: A species of Bairdia with compact carapace AB with large radius of curvature, PB short, with small radius of curvature and maximum of curvature located high, all dorsal parts regularly arched, strong overlap at DB.

Description: Carapace compact $(\mathrm{H} / \mathrm{L}=0.57-0.58)$; DB regularly arched with $\mathrm{PDB}, \mathrm{DB}$ and $\mathrm{ADB}$ in a regular arc of a circle at $\mathrm{LV}, \mathrm{ADB}$ slightly concave at $\mathrm{RV}$; $\mathrm{AB}$ with large radius of curvature with maximum of curvature located a little below mid - $\mathrm{H}$, a very fine ridge underlines the AB; VB quite horizontal to very slightly concave; PB short, with very small radius of curvature and 
maximum of curvature located around lower $1 / 3$ of $\mathrm{H}$, presence of the very thin ridge along the PB; bairdiid beak poorly expressed but present; strong overlap of LV on RV along all the dorsal margin with maximum at DB; overlap weak on all other parts of the carapace; surface smooth.

Remarks: This species is quite different from all the other species recognized in the Triassic. It could be compared to Bairdia jeancharlesi Forel, 2011 from the Smithian - Anisian of Tibet (Forel and Crasquin, 2011) but here the PB is shorter and the AB has a larger radius of curvature. Bairdiacypris triassica Kozur, 1971 from Late Anisian of Hungary (Kozur, 1971) has the same radius of curvature at $\mathrm{PB}$ and $\mathrm{AB}$ but $\mathrm{L}$ is really greater.

Stratigraphic and geographic range: Late Carnian of Sicily, Italy.

\section{Bairdia cf. finalyi (Méhes, 1911)}

Fig. $6 \mathrm{~s}$

Material: 2 carapaces

Dimensions: figured specimen $\mathrm{L}=858 \mu \mathrm{m} ; \mathrm{H}=570 \mu \mathrm{m}$

Stratigraphic and geographic range: Late Carnian (Tropites dilleri zone). Mufara

Formation in the east side of Monte Scalpello; (37²32'56.86' 'N; 14²40'30.64' 'E), Sicily, Italy (this work).

Remarks: The present specimens are very close to Bairdia finalyi (Méhes, 1911) from the Smithian - Ladinian of Balaton Highland, Hungary (Méhes, 1911; Kozur, 1971; Monostori, 1995), West Carpathians (Salaj and Jendrejakova, 1984), Guangxi, South China (Crasquin et al., 2006), Tibet (Forel and Crasquin, 2011). They differ only by a larger radius of curvature of AB here.

\section{Bairdia? sp. 2}

Fig. $6 \mathrm{t}$

Material:1 carapace 
Dimensions: $\mathrm{L}=843 \mu \mathrm{m} ; \mathrm{H}=357 \mu \mathrm{m}$

Stratigraphic and geographic range: Late Carnian (Tropites dilleri zone). Mufara

Formation outcropping in the east side of Monte Scalpello (37³2'56.86' 'N; 14²40'30.64'’E),

Sicily, Italy (this work).

Remark: this specimen has a remarkable and characteristic $\mathrm{AB}$ truncated in ventral part but there is not enough material to go further in the description.

\section{Bairdia sp. 3}

Fig. $6 \mathrm{u}$

\section{Material: 2 carapaces}

Dimensions: figured specimen $\mathrm{L}=800 \mu \mathrm{m} ; \mathrm{H}=440 \mu \mathrm{m}$

Stratigraphic and geographic range: Late Carnian (Tropites dilleri zone. Mufara

Formation outcropping in the east side of Monte Scalpello (37³2'56.86’'N; 1440’30.64'’E),

Sicily, Italy (this work).

Remarks: these specimens are very close to the specimens presented by Mette and MohatAghai (1999; Pl. 4; fig .4 - 5) as Bairdia sp. 7 from the Rhaetian of Tyrol in Austria. All these specimens could belong to a new species. The generic attribution is just at the limit between the two genera Bairdia and Urobairdia. As the ventral "blade" from AB to PB, characteristic of Urobairdia, is not clearly shown, we chose to let it in genus Bairdia.

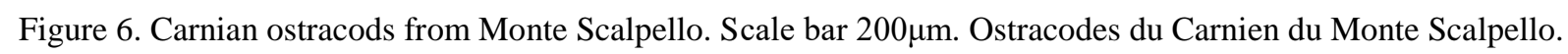

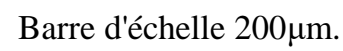

Genus Ptychobairdia Kollmann, 1960

Type species Ptychobairdia kuepperi Kollmann, 1960

Ptychobairdia kristanae Kollmann, 1960 
Fig. 7 a

1960 Ptychobairdia kristanae n. g. n. sp. - Kollmann, p. 99 - 100, pl. 25, figs. 6 - 9. 1960 Ptychobairdia medwenitschi n. g. n. sp. - Kollmann, p. 101 - 102, pl. 26, figs. 1 - 11. 1963 Ptychobairdia kristanae Kollmann - Kollmann, p. 181

Material: 1 carapace

Dimensions: $\mathrm{L}=1180 \mu \mathrm{m} ; \mathrm{H}=763 \mu \mathrm{m}$

Stratigraphic and geographic range: Late Carnian (Tropites dilleri zone). Mufara

Formation outcropping in the east side of Monte Scalpello (37'32'56.86'’N; $\left.14^{\circ} 40^{\prime} 30.64^{\prime \prime} \mathrm{E}\right)$ (this work), Rhaetian - Early Jurassic of Austria (Kollmann, 1960; 1963).

Remarks: The types figured by Kollmann (1960, Pl. 25, figs 6 - 9) have a ventral bulge more pronounced than here but intraspecific variations are very common in bairdiids

\section{Genus Bairdiacypris Bradfield, 1935}

Type species Bairdiacypris deloi Bradfield, 1935

Bairdiacypris cf. aequisymmetrica Mette, Honigstein et Crasquin .,2014

Fig. 7 b

Material: 1incomplete carapace

Dimensions: $\mathrm{L}=905 \mu \mathrm{m} ; \mathrm{H}=390 \mu \mathrm{m}$

Stratigraphic and geographic range: Late Carnian (Tropites dilleri zone). Mufara

Formation outcropping in the east side of Monte Scalpello (37 $\left.32^{\prime} 56.86^{\prime}{ }^{\prime} \mathrm{N} ; 4^{\circ} 40^{\prime} 30.64^{\prime \prime} \mathrm{E}\right)$,

Sicily, Italy (this work).

Remarks: the specimen discovered here is quite close to Bairdiacypris aequisymmetrica

Mette et al., 2014 from the Middle Anisian of Austria (Mette et al., 2014) by the general outline of the carapace. Unfortunately, the PB is broken here and the doubt stays. 
Material: 1 carapace.

Dimensions: $\mathrm{L}=730 \mu \mathrm{m} ; \mathrm{H}=350 \mu \mathrm{m}$.

Stratigraphic and geographic range: Late Carnian (Tropites dilleri zone). Mufara Fm. work).

Remarks: the specimen discovered here is quite close in general outline to Bairdiacypris mirautaae

Crasquin-Soleau and Gradinaru, 1996 from the Early Anisian of Dobrogea (Romania; Crasquin-

Soleau and Gradinaru, 1996) and Ladinian of Hungary (Monostori and Tóth, 2013). Here the carapace is shorter and the $\mathrm{PB}$ is less tapering.

Genus Anchistrocheles Brady and Norman, 1889

Type species Anchistrocheles fumata Brady, 1890

“Anchistrocheles” gemmellaroi n. sp.

Fig. $7 \mathrm{~d}-\mathrm{f}$

Etymology: The species is named in memory of the palaeontologistoGaetano Giorgio

Gemmellaro (1832-1904).

Material: Seven complete carapaces (three adults and four juveniles).

Holotype: A complete carapace (fig. 7 e), PMC. O 18 H 10/4/2017 (L= $742 \mu$ m; H = $440 \mu \mathrm{m})$.

Paratypes: Two complete carapaces (fig. $7 \mathrm{~d}$ : $\mathrm{L}=690 \mu \mathrm{m} ; \mathrm{H}=420 \mu \mathrm{m}$ and fig. $7 \mathrm{f}: \mathrm{L}=800$ $\mu \mathrm{m} ; \mathrm{H}=490$ ) and other not figured (PMC. O 68-73 P 10/4/2017).

Type locality: East side of Monte Scalpello (37³2'56.86’'N; 1440’30.64' 'E), Sicily, Italy Type level: Late Carnian (Tropites dilleri zone) in the dark grey clays of the Mufara Formation. 
Diagnosis: A species attributed to "Anchistrocheles", with bairdioid carapace sub trapezoidal, with rows of spines at $\mathrm{AB}, \mathrm{PVB}$ and $\mathrm{PB}$, flanks parallel in dorsal view.

Description: Bairdioid carapace sub trapezoidal in lateral view, with DB, PDB and ADB straights at both valves; $\mathrm{AB}$ with large radius of curvature; ventral margin concave at both valves; PB short and with a small radius of curvature; AB, PVB and PB strongly compressed laterally, without reticulation and ornamented with marginal spines at both valves; LV overlaps RV all around the carapace with maximum at dorsal parts; In dorsal view, flanks parallel (like in Orthobairdia genus), extremities strongly compressed laterally, a small sulcus is observable in front of mid-L; surface reticulated and small tubercles are observed on the surface in ADP and DP.

Remarks: This species is attributed to the genus "Anchistrocheles". It is clear that is not this genus which is a recent one and for which the specific determinations are made on soft parts. This generic attribution with "?" was used in the past, particularly for Triassic - Jurassic specimens exhibiting row of spines along AB and PB (Carnian, Late Triassic of Turkey (Forelet al., 2018); Rhaetian, Late Triassic of Austria (Bolz, 1971), Sinemurian, Early Jurassic of Germany and Switzerland (Beher et al., 2001; Beher, 2004), Bathonian, Early Jurassic of France (Sheppard, 1981 $\mathrm{PhD}$ MS). A revision of all these species and of the definition of a new genus is in preparation (Crasquin and Forel, work in progress).

"Anchistrocheles" gemmellaroi n. sp. could be compared to Bairdia marginosulcata Bolz, 1971 from the Late Norian - Rhaetian of Austria (Bolz, 1971) which presents a biconvex carapace in dorsal view and a smaller radius of curvature at $\mathrm{AB}$. The new species is very close from Anchistrocheles? spinosa from the Bathonian, Middle Jurassic of North-Western France with the flanks parallel and compressed extremities in dorsal view, with spines along AB and PVB and PB. This species was described and illustrated in the PhD thesis of Sheppard (1981). It seems that this species was never published and is considered here as unvalid. "Anchistrocheles" gemmellaroi n. 
Genus Nodobairdia Kollmann, 1963.

Type species Nodobairdia mammillata Kollmann, 1963

\section{Nodobairdia mammillata Kollmann, 1963}

Fig.7 g 1971 Nodobairdia mammillata Kollmann, 1963 - Kristan-Tollmann, p. 63, pl. 1, fig. 1 1971 Triebelina (Nodobairdia) triassica n. sp. - Bolz 1971, p. 216, pl. 16, figs. 229 - 232 1978 Nodobairdia mammillata Kollmann, 1963 - Kristan-Tollmann, p. 84, pl. 8, figs. 1 - 6 Stratigraphic and geographic range: Late Ladinian of Alps, Austria (Kollmann, 1963;

Kristan-Tollmann, 1971), Late Carnian of Alps, Austria (Kristan-Tollmann, 1978). Tropites dilleri zone of the Mufara Formation outcropping in the east side of Monte Scalpello $\left(37^{\circ} 32^{\prime} 56.86^{\prime}\right.$ 'N;

1440’30.64’'E) Sicily, Italy (this work); Norian - Rhaetian of Alps, Austria (Bolz, 1971).

Family Acratiidae Gründel, 1962

Genus Acratia Delo, 1930

Type species -Acratia typica Delo, 1930

Acratia maugerii n. sp.

Fig. $7 \mathrm{~h}-\mathrm{j}$

1991 Acratia sp. -Kristan-Tollmann, p. 196, pl.1, fig. 1

2013 Acratia goemoeryi (Kozur, 1970) - Monostori and Tóth, p. 6-7, pl. 4, only fig. 2

Etymology: The species is named in memory of Giuseppe Maugeri-Patanè palaeontologist in Catania University for his scientific engagement in Mesozoic palaeontology.

Material: Three complete carapaces.

Holotype: One complete carapace (fig. 7h, j), PMC. O 19 H 10/4/2017 (L=1110 $\mu$ m; H = $490 \mu \mathrm{m})$. 
Paratypes: Two complete carapaces, one figured PMC. O 74 P 10/4/2017 (fig. 7i: L=805

488

489 $\mu \mathrm{m}, \mathrm{H}=380 \mu \mathrm{m})$.

Type locality: East side of Monte Scalpello (37³2'56.86'’N; 1440'30.64'’E), Sicily, Italy. Type level: Late Carnian (Tropites dilleri zone), Mufara Formation.

Diagnosis: A new species of Acratia with short carapace $(\mathrm{H} / \mathrm{L}=0.45-0.46$ for the measured specimens), quite semicircular valves, straight VB and PB a little slender for the genus; acratian beak clearly expressed.

Description: Carapace short $(\mathrm{H} / \mathrm{L}=0.45-0.46$ for the measured specimens), quite semicircular in lateral view with $\mathrm{PB}$ more acute and slightly longer than $\mathrm{AB}$. Ventral margin almost straight, anteriorly ending with a pronounced acratian beak. Caudal process acute. Left valve wider than the right. Strong overlap especially in centro-ventral and antero-dorsal margin. Outer surface smooth. Carapace biconvex in dorsal view.

Stratigraphic and geographic range: Late Ladinian of NE Iran (Kristan-Tollmann, 1991) and Balaton Highland, Hungary (Monostori and Tóth, 2013) -Late Carnian (Tropites dilleri zone), Murfa Formation,Sicily, Italy (this work).

Remarks: the figured specimens are put in synonymy with Acratia sp., from the Late Ladinian from NE Iran (Kristan-Tollmann,1991) and one specimen figured by Monostori and Tóth (2013) from Ladinian of Balaton Highland, Hungary. Acratia triassica Kozur, 1970 (figs. 2-5 only, not fig. 1) is very close from the new species. However here the carapace is more rounded in dorsal part with a PB less acuminate.

Family Bythocyprididae Maddocks, 1969

Genus Bythocypris Brady, 1880

Type species Bythocypris reniformis Brady, 1880 
Material: 1 carapace.

Dimensions: $\mathrm{L}=568 \mu \mathrm{m} ; \mathrm{H}=300 \mu \mathrm{m}$.

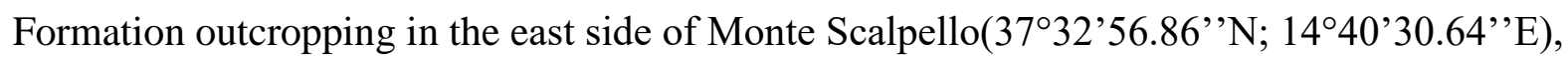

517 Sicily, Italy (this work).

Remarks: a specimen attributed with doubt (this genus is a Recent one defined on soft parts) to the genus Bythocypris. It is quite close to Bythocypris sp. B in Bolz, 1971 from the Norian - Rhaetian of Austria which has a very similar outline except here a VB more convex. We have no enough material to go further in determination.

\section{Pontocypris rara Méhes, 1911}

Material: 1 carapace.

Dimensions: $\mathrm{L}=662 \mu \mathrm{m} ; \mathrm{H}=288 \mu \mathrm{m}$.

533 1911) and Monte Scalpello (Tropites dilleri zone), (37³2'56.86’’N, 1440'30.64'’E) Sicily, Italy 534 (this work). 
Family Judahellidae Sohn, 1968

Genus Judahella Sohn, 1968

Type species Judahella tsorfatia Sohn, 1968

Judahella? montanarii n. sp.

Fig. $7 \mathrm{~m}-\mathrm{n}$

Etymology: The species. is named in memory of Loris Montanari geologist in Catania University. Material: Two complete carapaces.

Holotype: A complete carapace figured in Fig. 7m (PMC O 20 H 10/4/2017) (L= $450 \mu$ m; $\mathrm{H}=200 \mu \mathrm{m})$.

Paratype: A complete carapace figured in fig. 7n (PMC O 76 P 10/4/2017).

Type locality: East side of Monte Scalpello (37³2'56.86’’N; 1440’30.64’’E), Sicily, Italy.

Type level: Late Carnian (Tropites dilleri zone) in the dark grey clays of theMufara Formation.

Diagnosis: Judahella? montanarii n. sp. is characterized by subrectangular elongate carapace with a long straight DB ended by a caudal process, presence of lateral ridges and tubercles on valve surface.

Description: Lateral view: small carapace elongate subrectangular (Fig. 7m, n); long straight $\mathrm{DB}$ ended by a short caudal process. Upper part of $\mathrm{AB}$ straight with an angle of $110^{\circ}$ with $\mathrm{DB}$; maximum of convexity of $\mathrm{AB}$ located below mid-H;VB slightly convex, surface of valves are ornamented by large ridges and nodes reticulated; dorsal ridges overpass hinge line; the largest and strong ridge is arched and shows variable thickness through its length; it begins in the anterodorsal margin, moves downwards until reaching the centre of the ventral margin and back again towards the postero-dorsal margin initially curved and then straight and facing forward. Another thinner ridge is present along the outer edge of the anterior margin of the valves. Two stubby nodes are present in the posterior dorsal and in the central anterior area.

Dorsal view: hinge line long and straight; caudal process strongly compressed laterally; 
ridges and nodes very prominent by absence of ventro-lateral swollen process

Remarks: The new species is attributed to Judahella? The doubt comes from the presence of the posterior caudal process never described in the genus. The present specimens could be compared to Judahella tsorfatia Sohn, 1968 from the Ladinian of Eastern France (Sohn, 1968) by their similar subrectangular lateral outline. But here the nodes are gathered in ridges and there is a caudal process. Judahella tuberculifera (Gümbel, 1869) from Carnian of Italian Alps (Gümbel, 1869; Lieberman, 1979), Anisian - Ladinian of Poland (Styk, 1958), Ladinian of France (Sohn, 1968), Anisian of Germany (Knüpfer and Kozur, 1968), Ladinian of Spain (Kozur et al., 1974) and Anisian of South China (Kristan-Tollmann, 1983) has a general dorsal outline which can evoke the new species.

Family Glorianellidae Snejder, 1960 emend. Kozur 1970

Genus Mockella Bunza and Kozur, 1971

Type species Mockella marinae (Kozur, 1970)

Mockella muelleri Bunza and Kozur, 1971

Fig. $7 \mathrm{o}-\mathrm{p}$

1971 Mockella muelleri n. sp. - Bunza and Kozur, p. 8 - 9, pl. 1, fig. 12

Material: 2 carapaces, 1 figured.

Dimensions: $\mathrm{L}=390 \mu \mathrm{m} ; \mathrm{H}=235 \mu \mathrm{m}$ (figured specimen).

Stratigraphic and geographic range: Late Carnian of Tyrol, Austria (Bunza and Kozur, 1971) and east side of Monte Scalpello (37³2’56.86’’N, 1440’30.64’’E) Sicily, Italy (this work).

Fig. 7. Carnian ostracods from Monte Scalpello. Scale bar $=200 \mu \mathrm{m}(\mathrm{a}-1) ; 100 \mu \mathrm{m}(\mathrm{m}-\mathrm{p})$. Ostracodes du Carnien du Monte Scalpello. Barre d'échelle $200 \mu \mathrm{m}(\mathrm{a}-1), 100 \mu \mathrm{m}(\mathrm{m}-\mathrm{p})$. 


\section{Conclusion.}

Carnian Ostracods are known worldwide, from Alaska (Sohn, 1968), Alps (Kristan-

Tollmann, 1969, 1978; Kollmann, 1963), Austria (Kristan-Tollmann, 1971, 1973, 1988; Bunza and

Kozur, 1971), British Columbia (Arias and Lord, 2000), Germany (Gründel, 1965; Bunza and

Kozur, 1971), Hungary (Kristan-Tollmann et al., 1991; Kozur 1971, 1972; Bunza and Kozur, 1971), and Kozur, 1971); Italy (Kristan-Tollmann, 1971, 1973, 1982, 1983; Liebermann, 1979), Slovenia (Kolar-Jurkovsek ,1990) and Turkey (Forel et al., 2018). The turn-over between Palaeozoic and Mesozoic ostracod fauna is long, at least 14 My, began in the early Late Permian (in the Early

Wuchiapingian) and is considered to be ended in the Anisian (Crasquin and Forel, 2013). However, some Palaeozoic genera are still present in the Carnian: three Kirkbyidae (Carinaknightina, Kirkbya, Tubulikirkbyia?) in Turkey deep environment (Forel et al., 2018) and Acratia, discovered as well in Turkey (Forel et al., 2018) whose presence is confirmed here. is not easy. It is necessary to consider both the structure, composition and taphonomic to note that the ostracods specimens are predominantly represented by integer carapaces and rare valves. This could suggest a rapid burial in situ in a high sedimentation rates environment, since the valves, after the death of the specimens, tend to open in a few hours (Guernet \& Lethiers, 1989). layer associations deposited in extremely rapid distal sedimentation basins. 
Another important datum concerns the size of all the found skeletal remains. Gastropods,

614 bivalves, crinoids and brachiopods remains are all of the same little size; also the ostracod

615 thanatocoenosis structure is characterized by abundance of juveniles and rare adults; according to

616 van Harten (1986), all that would suggest strong phenomena of dimensional selection and,

617 therefore, displaced of faunas and sediments ().

From the sedimentological point of view the study area is characterized by the extreme

abundance of pelitic sediments with interbedded sandy levels sometimes rich in oolites. Sometimes

this sediments shown in the outcrop, particular sedimentary structures as parallel lamination, wavy

lamination and vortices structures, all features that make one think of a high-energy sedimentation environment.

From a palaeogeographic point of view, the Mufara Formation outcropping in the studied area, is located inside the pelagic Imerese Basin that is delimited by the carbonate platforms of Martini, 2009).

On the basis of all these data it is possible to hypothesize for the ostracods association an environment characterized by high sedimentation rates and high depositional energy, features that controls strongly, today as in the past, the colonization of the bottom as well as the composition and structure of the populations (cf. Di Geronimo \& Robba, 1989; Sciuto, 2014). According to Carillat and Martini (2009), the Monte Scalpello area, it could be a probably, distal turbiditic sedimentary environment not necessarily very deep (Fig. 8). The collection of further faunistic and sedimentological data (whose finding and observation is made extremely difficult by the intense agricultural activity) can lead to more detailed information on the Triassic palaeo-environment of 
Fig. 8. Schematic palaeoenvironmental model for the Late Carnian Mufara Formation (see also Fig. 3). Modèle

paléoenvironnemental schématique de la Formation Mufara du Carnien supérieur (voir également fig. 3)

642

Declaration of interest.

The authors declare that they do not have any links of interest.

Acknowledgements

The authors are grateful to the reviewers and the editors for detailed suggestions and

\section{REFERENCES}

655

Anderson, F.W., 1964. Rhaetic ostracoda. Bulletin of the Geological Survey of Great Britain 21,

657 $133-174$.

Arias, C., Lord, A., 2000. Upper Trias marine ostracoda from the Queen Charlotte Islands British Columbia Canada. Revista Española de Micropaleontologia 32, 175-192.

Beher, E., 2004. Ostracodenfauna und Biostratigraphie im Ober-Sinemurium von Süddeutschland und der Nordschweiz. Stuttgarter Beiträge zur Naturkunde Serie B (Geologie und Paläontologie) 349, 1-170. 
Beher, E., Franz, M., Schweizer, V., 2001. Zur Ostracodenfauna des Ober-Sinemurium und untersten Unter-Pliensbachium im Gebiet von Tuningen (Baden-Württemberg). Neues Jahrbuch für Geologie und Paläontologie, Abhandlungen 219, 329-391.

Bolz, H., 1971. Die Zlambach-Schichten (alpine Obertrias) unter besonderer Berücksichtigung der Ostrakoden, 1: Ostrakoden der Zlambach-Schichten, besonders Bairdiidae. Senckenbergiana Lethaea 52, 129-283.

Brady,G. S.,1880. Report on the Ostracoda dredged by H.M.S. Challenger during the Years 18731876. In: Report on the scientific results of the voyage of H.M.S. Challenger. Zoology 1, 1184.

Brady, G. S., 1890. On Ostracoda collected by H.B. Brady, Esq., L.L.D., F.R.S. in the South Sea Islands. Transactions of the Royal Society of Edinburgh: Earth Sciences 35, 489-525.

Brady, G. S., Norman, A. M., 1889. A Monograph of the Marine and Freshwater Ostracoda of the North Atlantic and of North Western Europe. Sect I. Podocopa. Scientific Transactions of the Royal Dublin Society 2, 63-270.

Bradfield, H. H., 1935. Pennsylvanian ostracods of the Ardmore Basin, Oklahoma. Bulletin of American Paleontology 22, 1-145.

Bunza, G., Kozur, H., 1971. Beiträge zur Ostracodenfauna der tethyalen Trias. GeologischPaläontologische Mitteilungen Innsbruck 1, 1-76.

Calcara P., 1840. Monografie dei generi Clausilia e Bulimo, coll'aggiunta di alcune nuove specie di conchiglie siciliane esistenti nella collezione della Sig. Teresa Gargotta in Salinas, 54 p.

Calcara, P., 1845. Cenno sui molluschi viventi e fossili della Sicilia da servire di supplement ed insieme di critiche osservazioni all'opera di R. A. Philippi.. Reale stamperia e Libreria Palermo $65 \mathrm{p}$ 
Carrillat, A., Martini, R., 2009. Palaeoenvironmental reconstruction of the Mufara Formation (Upper Triassic, Sicily): High resolution sedimentology, biostratigraphy and sea-level changes Palaeogeography, Palaeoclimatology, Palaeoecology 283, 60-76.

Catalano, R., D’Argenio, B., 1982. Schema geologico della Sicilia occidentale. In R. Catalano and B. D’Argenio (eds.) Guida alla geologia della Sicilia occidentale. Guide geologiche regionali, Memorie Società Geologica Italiana suppl. A 24, 9-41.

Crasquin, S., Forel, M.B., 2013. Ostracods (Crustacea) through Permian - Triassic events. EarthScience reviews $137,52-64$

Crasquin, S., Forel, M.-B., Feng, Q., Yuan, A., Baudin, F., Collin, P. Y., 2010. Ostracods (Crustacea) through Permian-Triassic boundary in South China: the Meishan stratotype (Zhejiang Province). Journal of Systematic Palaeontology 8, 331-370.

Crasquin-Soleau, S., Galfetti, T., Bucher, H., 2006. Early Triassic ostracods from South China. Rivista Italiana di Paleontologia e Stratigrafia 112 (1), 55-75.

Crasquin-Soleau, S., Gradinaru, E., 1996. Early Anisian ostracode fauna from the Tulcea unit (Cimmerian Notrh Dobrogean orogeny, Romania). Annales de Paléontologie 82, 59-116.

Dal Sasso, C., Insacco, G., Chiarenza, A. A., Di Franco, D., Reitano, A, 2014. First record of ichthyosaurus in Sicily (Upper Triassic of Monte Scalpello, Catania province). Rivista Italiana di Stratigrafia e Paleontologia 120 (1), 71-82.

Delo, D.M., 1930. Some Upper Carboniferous ostracods from the Shale Basin of Western Texas. Journal of Paleontology 4, 152-178.

\section{Di Geronimo, I., Robba, E., 1989, The structure of benthic communities in relation to basin} stability. Memorie dell' Accademia dei Lincei 80, 341-352.

Di Paolo, L., Aldega, L., Corrado, S., Mastalerz, M., 2012. Maximum burial and unroofing of Mt. Judica recess area in Sicily: implication for the Apenninic-Maghrebian wedge dynamics. Tectonophysics 530-531, 193-207. 
Drexler, E., 1958. Foraminiferen und Ostracoden aus dem Lias von Siebeldingen/Pfalz. Geologisches Jahrbuch 75, 475-554.

Egorov, V. G., 1950. Ostrakody franskogo iarusa Russkoi platformy, 1. Kloedenellidae: MoscowLeningrad Vses. Neft. Nauchno-Issled. Geol. Razved. Inst., Moscov, Filial, 140 p.

Forel, M. B., Crasquin, S., 2011. In the aftermath of the Permian-Triassic boundary mass extinction: ostracod new species and genus from South Tibet. Geodiversitas 33, 247-263.

Forel, M.B., Tekin, U.K., Okuyucu, C., Bedi, Y., Tuncer, A., Crasquin, S., 2018. Discovery of a long-term refuge for ostracods (Crustacea) after the end-Permian extinction: a unique Carnian (Late Triassic) fauna from the Mersin Melange, southern Turkey. Journal of Systematic Palaeontology 16 (3).

Gemmellaro, G. G., 1860. Cenno sopra taluni organici fossili del Turoniano e Nummulitico di Judica. Atti Accademia Gioenia di Scienze Naturali in Catania 2 (15), 268-284.

Gemmellaro, G. G.,1904. I Cefalopodi del Trias Superiore della regione occidentale della Sicilia. Giornale di Scienze Naturali ed Economiche di Palermo 24, 319 p.

Gerry, E., Honigstein, A., Rosenfeld, A., Hirsch, F., Eshet, Y., 1988. The Carnian salinity crisis: ostracods and palynomorphs as indicators of palaeoenvironment. In R. Whatley \& C. Maybury (eds.) Ostracoda and global events. Chapman \& Hall, London, 87-99.

Golonka, J., 2007. Late Triassic and Early Jurassic palaeogeography of the world. Palaeogeography, Palaeoclimatology, Palaeoecology 244, 297-307.

Grasso, M., 2001. The apenninic- Maghrebian orogen in southern Italy, Sicily and adjacent areas. In Vai , G. B., Martini, I. P. (eds.) Anatomy of an Orogen: The Apennines and Adjacent Mediterranean Basins . Kluver Acad. Publ. GB, 255-286

Gründel, J. ,1962. Zur Taxionomie der Ostracoden der Gattendorfia Stufe Thüringens. Freiderger Forschungchelfe C 151, 51-105. 
Gründel, J., 1964. Zur Gattung Healdia (Ostracoda) und zu einigen verwandten Formen aus dem unter Jura. Geologie 13, 1- 469

Gründel, J., 1965. Zwei neue Ostracoden-Arten aus dem unteren Keuper Thueringens. Palaeontologische Zeitschrift 39, 234-239.

Gründel, J., 1967. Zur Grossgliederung der Ordnung Podocopida G. W. Müller, 1894. Neues Jahrbuch fur Geologie and Palaontologie, Monatshefte 6, 321-332

Guernet, C. \& Lethiers, F., 1989, Ostracodes et recherche des milieux anciens: possibilités et limites: Bulletin de la Societé Géologique de France 8 (5), 577-588.

Gümbel, C.W., 1869. Uber Foraminiferen, Ostracoden und mikroskopische Tier-Uberreste in den St. Cassianer und Raibler Schichten. Jahrbuch Geologischen Reichsanstalt 19, 175-186.

Harlton, B. H., 1933. Micropaleontology of the Pennsylvanian Johns Valley Shale of Ouachita Mountains, Oklahoma and its relationships to the Mississippian Caney Shale. Journal of Paleontology 7, 3-29.

Harten, D. van, 1986. Use of ostracodes to recognize dowslope contamination in paleobathymetry and a preliminary reappraisal of the paleodepth of Prasas Marls (Pliocene), Crete, Greece. Geology 14, 856-859.

Jenks, J. F., Monnet, C., Balini, M., Brayard, A., Meier, M., 2015. Biostratigraphy of Triassic Ammonoids. In Klug,C. et al. (eds.), Ammonoid Paleobiology: From macroevolution to paleogeography, Topics in Geobiology 44, 329-388.

Knupfer, J., Kozur, H., 1968. Eine neue Ostracodengattung aus der Trias des germanischen Binnenbeckens. Monatsberichte der Deutschen Akademie der Wissenschaften Berlin 10, $322-331$.

Kolar-Jurkovsek, T., 1990. Microfauna of Middle and Upper Triassic in Slovenia and its biostratigraphic significance. Geologija 33, 21-170.

Kollmann, K., 1960. Ostracoden aus der alpinen Trias Österreichs. I Parabairdia n. g. und Ptychobairdia n. g. (Bairdiidae). Jahrbuch der Geologischen Bundesanstalt 5, 79-105. 
Kollmann, K., 1963. Ostracoden aus der alpinenTrias. II.- Weitere Bairdiidae. Jahrbuch der Geologischen Bundesanstalt Wien 106, 121-203.

Kozur, H., 1970. Neue Ostracoden-Arten aus dem Obersten Anis des Bakonyhochlandes (Ungarn). Berichte des naturwissenschaftlich-medizinischen Vereins in Innsbruck 58, 384-428.

Kozur, H. 1971. Die Bairdiacea der Trias. Teil 3: Einige neue Arten triassischer Bairdiacea und Bemerkungen zur Herkunft der Macrocyprididae (Cypridacea). Geologisch Paläontologische Mitteilungen Innsbruck 1, 1-18.

Kozur, H. 1972. Die Bedeutung triassischer Ostracoden fur stratigraphische und palaookologische Untersuchungen. Mitteilungen der Gesellschaft fur Geologie und Bergbaustudien 21, 623660.

Kozur, H., Kampschuur, W., Mulder-Blanken, C. W. H., Simon, O. J., 1974. Contribution to the Triassic ostracode faunas of the Betic Zone (southern Spain). Scripta Geologica 23, 1-57.

Kristan-Tollmann, E., 1969. Zur stratigraphischen Reichweite der Ptychobairdien und Anisobairdien (Ostracoda) in der alpinen Trias. — Geologica et Palaeontologica 3, 81—95.

Kristan-Tollmann, E., 1970. Einige neue Bairdien (Ostracoda) aus der alpinen Trias. Neues Jahrbuch für Geologie und Paläontologie 135, 268-310.

Kristan-Tollmann, E. 1971. Weitere Beobachtungen an skulptierten Bairdiidae (Ostracoda) der alpinen Trias. Neues Jahrbuch für Geologie und Paläontologie 139, 57-87.

Kristan-Tollmann, E., 1973. Zur phylogenetischen und stratigraphischen Stellung der triadischen Healdiiden (Ostracoda) II. Erdoel-Erdgas-Zeitschrift 89, 150-155.

Kristan-Tollmann, E., 1978. Bairdiidae (Ostracoda) aus den obertriadischen Cassianer Schichten der Ruones-Wiesen bei Corvara in Südtirol. Schriftenreihe der Erdwissenschaftlichen Kommissionen, Österreichische Akademie der Wissenschaften 4, 77-104.

Kristan-Tollmann, E., 1982. Bemerkungen zur triadischen Ostracoden-Gattung Mostlerella. Neurs Jahrbuch fur Geologie und Paleontologie 9, 560-572. 
Kristan-Tollmann, E., 1983. Ostracoden aus dem Oberanis von Leidapo bei Guiyang in Süd China. Neue Beiträge zur Biostratigraphie der Tethys-Trias, 121-176.

Kristan-Tollmann, E., 1988. Coccolithen aus den Älteren Allgäuschichten (Alpiner Lias, Sinemur) von Timor, Indonesien. Geologische und Paläontogische Mitteilungen Innsbruck 15, 71-83.

Kristan-Tollmann, E., 1991. Ostracods from the Middle Triassic Sina Formation (Aghdarband Group) in NE-lran. Abhandlungen der Geologischen Bundesanstalt 38, 195-200.

Kristan-Tollmann, E., Tollmann, A., Hamedani, A., 1979. Beitrage zur Kenntnis der Trias von Persien. I. Revision der Triasgliederung, Rhäfazies im Raum von Isfahan und Kössener Fazieseinschlag bei Waliabad SE Abadeh. Mitteilungen der Gesellschaft der Geologie und Bergbaustudenten in Osterreich 70, 119-186.

Kristan-Tollmann, E., Hasibuan, F. 1990. Ostracoden aus der Obertrias von Misol (Indonesien). Mitteilungen der Osterreichischen Geologischen Gesellschaft, 82, 173-181.

Latreille, P.A., 1806. Genera crustaceorum et insectorum secundum ordinem naturalem in familias disposita, iconibus exemplisque plurimis explicata. Parisiis et Argentorati, $303 \mathrm{p}$.

Lentini, F., 1974. Caratteri stratigrafici e strutturali della zona di Monte Judica (Sicilia Orientale). Rivista Mineraria Siciliana 145-147, 71-96.

Lentini, F., Grasso, M., Carbone, S., 1987. Introduzione alla geologia della Sicilia e guida all'escursione. 60 pp. Catania.

Lieberman, H. M., 1979. Die Bivalven- und Ostracodenfauna von Raibl und ihr stratigraphischer. Verhandlungen der Geologischen Bundesanstalt 2, 85-131.

Lucas, S. G., 2010. The Triassic timescale: an introduction. In LUCAS, S. G. (ed.) The Triassic Timescale. Geological Society, London, Special Publications 334: 1-16.

Maddocks, R.F., 1969. Revision of Recent Bairdiidae. Bulletin of the United States National Museum 295, 1-126. 
Marinelli, O. 1899. Osservazioni geologiche sopra i terreni secondari del gruppo del M. Judica in Sicilia. Atti della Reale Accademia Nazionale dei Lincei, Rendiconti della Classe di Scienze Fisiche, Matematiche e Naturali 5, 8 (1), 404-412.

Maugeri Patanè, G., 1934. Sopra alcuni coralli del Trias superiore di M. Scalpello (Enna) Relationes Consessuum Societatis Gioieniae Catinensis Natururalium Scientiarum 67, 9 p.

McCoy, F., 1844. A synopsis of the characters of the Carboniferous Limestone fossils of Ireland. Dublin University Press, Dublin, 207 pp.

Méhes, G., 1911. Über Trias-Ostrakoden aus dem Bakony. Resultate der Wissenschaftlichen. Erforschung des Balatonsees, 1-38.

Mette, W., Mohtat-Aghai, P., 1999. Ostracods and foraminifera from Upper Triassic intrashelf basin deposits in the Northern Calcareous Alps. Geologisch Paläontologische Mitteilungen Innsbruck 24, 45-77.

Mette, W., Honigstein, A., Crasquin, S., 2014. Deep-water ostracods from the Middle Anisian (Reifling Formation) of the Northern Calcareous Alps (Austria). Journal of Micropalaeontology 34, 71-91.

Michelsen, O., 1975. Lower Jurassic biostratigraphy and ostracods of the Danish Embayment. Danmarks Geologiske Undersoegelse, Raekke 2 104, 1-287.

Monostori, M., 1995. Environmental significance of the Anisian Ostracoda fauna from the Forras Hill near Felsoors (Balaton Highland, Transdanubia, Hungary). Acta Geologica Hungarica $39,37-56$.

Monostori, M., Tóth, E., 2013. Ladinian (Middle Triassic) silicified ostracod faunas from the Balaton Highland (Hungary). Rivista Italiana di Paleontologia e Stratigrafia 119, 303-323.

Montanari, L., 1987. Lineamenti stratigrafico - paleogeografici della Sicilia durante il Ciclo Alpino. Memorie della Società Geologica Italiana 38, 361-406. 
Moore, R. C., 1961. Treatise of Invertebrate Paleontology. Part Q. Arthropoda 3, Crustacea, Ostracoda: Geological Society of America and University of Kansas Press, 442p.

Muller, G. W. 1894. Die Ostracoden des Golfes von Neapel und der angrenzenden Meeres Abschnilte. Fauna und Flora des golfes von Neapel 21, 1-404.

Nelli, B., 1899a. Il Raibliano del Monte Judica nella provincia di Catania, Atti della Reale Accademia Nazionale dei Lincei, Rendiconti della Classe di Scienze fisiche, matematiche e naturali 5, 8(1), $91-92$

Nelli, B., 1899b. Il Raibl nei dintorni di M. Judica. Bollettino della Società Geologica Italiana 18 (2), 211-223.

Oertli, H. J., 1971. The aspect of ostracode faunas - a possible new tool in petyroleum sedimentology: Bulletin du Centre de Recherches de Pau 5, suppl.: 137-151.

Özdikmen, H., 2010. Substitute names for three genera of Ostracoda (Crustacea). Munis Entomology and Zoology, Scientific note 5, 315

Pokorny, V., 1964. Some paleoecological problems in marine ostracode faunas, demonstrated on the Upper Cretaceous ostracodes of Bohemia, Czechoslovakia: Pubblicazioni della Stazione Zoologica di Napoli 33 Suppl.: 462-479.

Preto, N., Kustatscher, E., Wignall, P. B., 2010. Triassic climates. State of the art and perspectives. Palaeogeography, Palaeoclimatology, Palaeoecology 290, 1-10.

Reuss, A. E., 1869. Zur fossilen Fauna der Oligocänschichten von Gaas. Sitzungsberichte der österreichischen Akademie der Wissenschaften, mathematisch-naturwissenschaftliche Klasse Abt.1. 59 (3), 446-488.

Roundy, P. V., 1926. Mississippian formations of the Saba County, New York and its fauna. United States Geological Survey, Professional Paper 146, 5-8.

Salag, J., Jendrejakova, O., 1984. Ecology and facial relation of some groups of Triassic foraminifers and ostracods of stratigraphic importance. Geologickÿ Zbornǐk - Geologica Carpathica 35(2), 231-240. 
Sandberg, F., 1866. Die Stellung der Raibler Schichten in dem frankisichen und schwabischen Keuper. Neues Jahrbuch für Mineralogie, Geologie und Paläontologie, 41.

Sars, M., 1863. Bemaerkninger over fire norske Hydroider. Forhandlinger i Videnskabs-selskabet i Christiania 1862, 25-39.

Sars, G. O., 1866. Oversight af Norges marine Ostracoder. Forhandlinger i Videnskabs-Selskabet i Christiania, 1865, 1-130.

Scalia, S., 1907. I fossili del Trias superiore dell’Acquanova e di Paraspora. Bollettino dell' Accademia Gioenia di Scienze Naturali in Catania 2 (1-2), 10-12.

Scalia, S.,1907. La fauna del Trias superiore del gruppo montuoso di Judica. Bollettino dell’ Accademia Gioenia di Scienze Naturali in Catania 2 (3-4), 17-25.

Scalia, S., 1909. Il gruppo di M. Judica. Bollettino della Società Geologica Italiana 28, 269-340.

Scalia, S., 1910-1914. La fauna del Trias superiore del gruppo del M. Judica: Parti 1-3. Atti dell'Accademia Gioenia di Scienze Naturali in Catania 5 (3-5-7), p. 51+58+25.

Schmidt di Friedberg, P., Trovò, A., 1962.Contribution à l'étude structurale du groupe du Monte Judica (Sicile orientale). Bulletin de la Société Géologique de France 4(5), 754-759.

Sciuto, F., 2014. Initial report on ostracod fauna from the Messina Straits (Ionian Sea, northeastern Sicily). Bollettino della Società Paleontologica Italiana 53 (2), 121-134.

Sebe, O., Crasquin, S., Gradinaru, E., 2013. Early and Middle Anisian (Triassic) deep-water ostracods (Crustacea) from North Dobrogea (Romania). Revue de Paléobiologie 32, 509529.

Sheppard, L. S., 1981. Middle Jurassic Ostracoda from Southern England and Northern France. Unpublished PhD thesis, University of London: 358 pp.

Schornikov, E .I., Michailova E. D., 1990. Ostracods Bythocytheridae at early stage of development. Comparative morphology, paleoecology and evolutionary pathways. Nauka, Moskva, 1-280 p.

Snejder, G. F., 1960. Fauna ostracod nizne triasovych otlozenij Prikaspijskoj nizmennosti. Trudy Kiuge 5, 287-303.

Sohn, I. G., 1968. Triassic Ostracodes from Makhtesh Ramon, Israel. Bulletin of the Geological Survey of Israel 44, 1-71. 
Speranza, F., Minelli, L., 2014. Ultrathick Triassic dolomites control the rupture behavior of the central Apennine seismicity: Evidence from magnetic modeling of the L'Aquila fault zone. Journal of Geophysical Research: Solid Earth 119, 1-15. ,

Sylvester-Bradley, P. C., 1961. Suborder Metacopina Sylvester-Bradley, n. suborder. Q358-359. In Moore, R. C. (ed.). Treatise of invertebrate paleontology. Part Q, Arthropoda 3, Crustacea, Ostracoda. Geological Society of America, Boulder, CO and University of Kansas Press, Lawrence, KS, 442 pp.

Styk, O., 1958. Triassic microfauna in the neighbourhood of Chrzanow and the northwestern part of the Mesozoic periphery of the Swiety Kryzyz Mts. Bulletin Poland Instytut Geologiczny 121, Micropalaeontological researches in Poland 3, 163-176.

Széles, M., 1965. Ostracodåk a Bakonyi Nosztori-Volgy felsokarni rétegeibol. Földtani közlöny45, 412-417.

Tollmann, A., 1976. Analyse des klasschen nordalpinen Mesozoikums. Monographie des Nördlichen Kalkalpen 2, 1-580.

Ulrichs, M., 1970. Variability of some Ostracods from the Cassian beds (Alpine Triassic) depending on the ecology. Bulletin du Centre Recherches de Pau - SNPA 5, 695-715.

\section{Captions. Légendes}

Fig. 1. Geographical location of the sampling area. Localisation géographique de la zone d'étude.

Fig. 2. Structural scheme of the central Mediterranean area with the location of the study area (after Grasso, 2001 modified). Schéma structural de la Méditerranée centrale avec la localisation de la zone d'étude (d'après Grasso, 2001 modifié)

Fig. 3. Schematic palaeogeographic reconstruction of Pangaea and Neo-Tethys in Late Triassic times (after Speranza \& Minelli (2014), Golonka, 2007 and Preto et al., 2010 
modified). Reconstruction paléogéographique schématique de la Pangée et de la Néo-Téthys à la fin du Trias (d'après Speranza \& Minelli, 2014; Golonka, 2007 et Preto et al., 2010 modifié).

Fig. 4. Geological map of the Monte Scalpello area (after Lentini, 1974 and Di Paolo et al. 2012, modified). Carte géologique de la région de Monte Scalpello (d'après Lentini, 1974 et Di Paolo et al. 2012, modifié)

Fig. 5. Carnian Ammonoid zones (after Lucas 2010 modified). Zones à ammoinoidés du Carnien (d'après Lucas 2010, modifié).

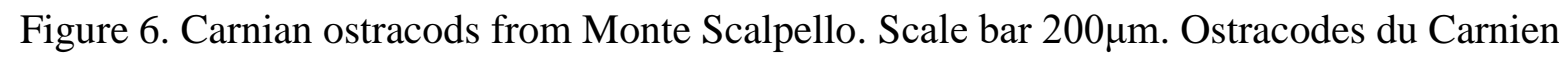

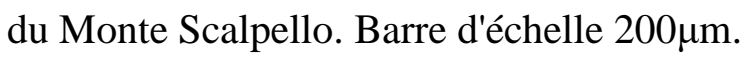

a - b. Ogmoconchella felsooersensis (Kozur, 1970). a. Complete carapace, right external lateral view; b. Complete carapace, dorsal view.

c - d. Healdia sp. c. Complete carapace, right external lateral view; d. Complete carapace, dorsal view.

e. Bektasia sp. 1. Complete carapace, left external lateral view.

f - h. Hiatobairdia subsymmetrica Kristan-Tollmann, 1970. f. Complete carapace, right external lateral view; g. Complete carapace, right external lateral view; h. Complete carapace, dorsal view.

i - j. Bairdia cf. humilis Monostori, 1995. i. Complete carapace, right external lateral view; j. Complete carapace, dorsal view.

k - 1. Bairdia cf. deformata Kollmann, 1963. k. Complete carapace, right external lateral view; $\mathbf{l}$. Complete carapace, dorsal view.

m. Bairdia cassiana (Reuss, 1869), complete carapace, right external lateral view.

n, o. Bairdia sp. 1. Complete carapace, right external lateral view.

p. Bairdia balatonica Méhes, 1911. Complete carapace, right external lateral view. 
q - r. Bairdia scaliai n. sp. q. Paratype, complete carapace, left external lateral view; r. Holotype, complete carapace, right external lateral view.

s. Bairdia cf. finalyi (Méhes, 1911). Complete carapace, right external lateral view.

t. Bairdia? sp. 2. Complete carapace, right external lateral view.

u. Bairdia sp. 3. Complete carapace, right external lateral view.

Fig. 7. Carnian ostracods from Monte Scalpello. Scale bar $=200 \mu \mathrm{m}(\mathrm{a}-1) ; 100 \mu \mathrm{m}(\mathrm{m}-\mathrm{p})$. $(m-p)$. view .

c. Bairdiacypris cf mirautaae Crasquin-Soleau and Gradinaru, 1996. Complete carapace, right

a. Ptychobairdia kristinae Kollmann, 1960. Complete carapace, right external lateral view.

b. Bairdiacypris cf. aequisymmetrica Mette et al.,2014. Complete carapace, right external lateral external lateral view.

d - f. “Anchistrocheles" gemmellaroi sp. nov. d. Paratype, complete carapace, left external lateral view,

e. "Anchistrocheles" gemmellaroi sp. nov. Holotype, complete carapace, right external lateral view. f. Paratype, complete carapace, dorsal view.

g. Nodobairdia mammillata Kollmann, 1963. Complete carapace, right external lateral view.

h - j. Acratia maugerii n. sp. h. Holotype, complete carapace, right external lateral view; i. Paratype, complete carapace, left external lateral view; j. Paratype, complete carapace, dorsal view.

k. Bythocypris? sp. 1. Complete carapace, right external lateral view.

1. Pontocypris rara Méhes, 1911. Complete carapace, left external lateral view.

m - n. Judahella? montanarii n. sp. m. Holotype, left valve, external lateral view; n. Paratype, complete carapace, dorsal view. 
971 o - p. Mocklella muelleri Bunza and Kozur, 1971. o. Complete carapace, left external lateral view; p. Complete carapace, dorsal view.

973

Fig. 8. Schematic palaeoenvironmental model for the Late Carnian Mufara Formation basin

975 (see also Fig. 3). Modèle paléoenvironnemental schématique de la Formation Mufara du Carnien 976 supérieur (voir également fig. 3)

977

978 


\section{TYRRHENIAN SEA}

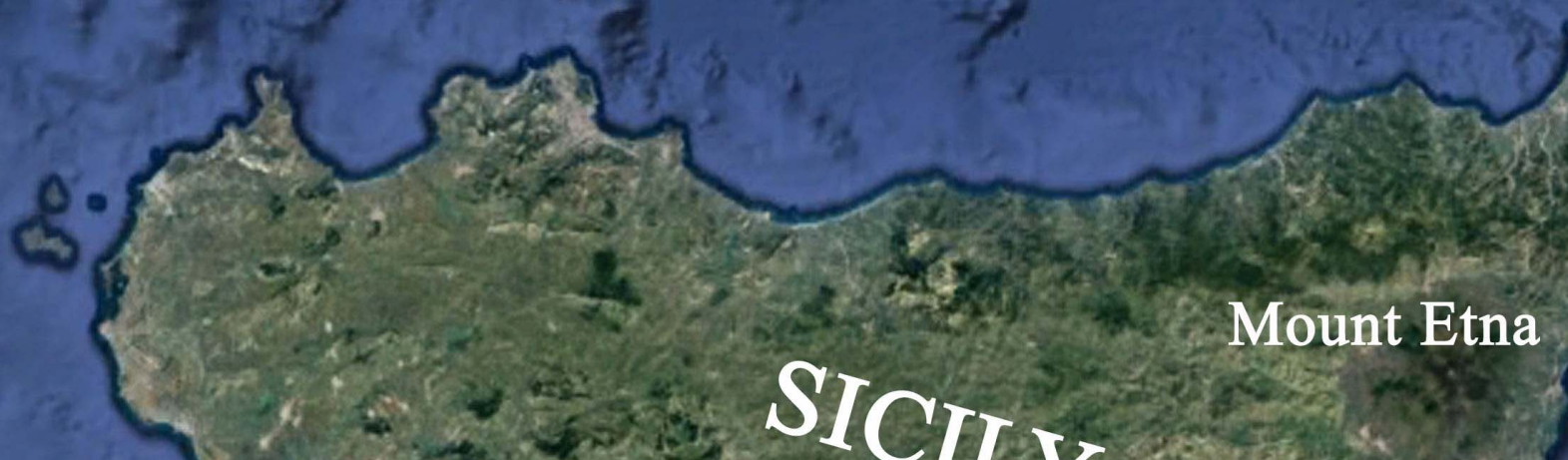

\section{SICILY \\ Monte Scalpello}

\section{IONIAN SEA}

Dittaino River

Catenanuova Nonte soapello Monte solpe Sampling station Monte soatello

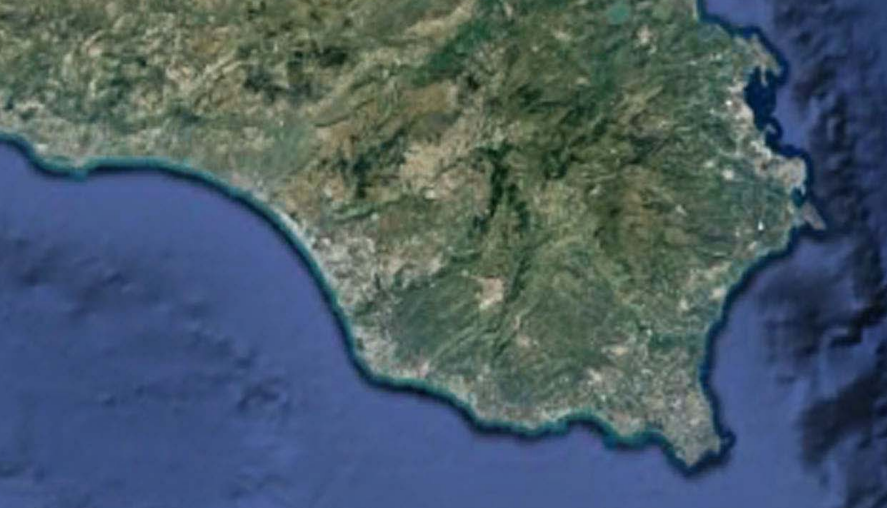

inc.
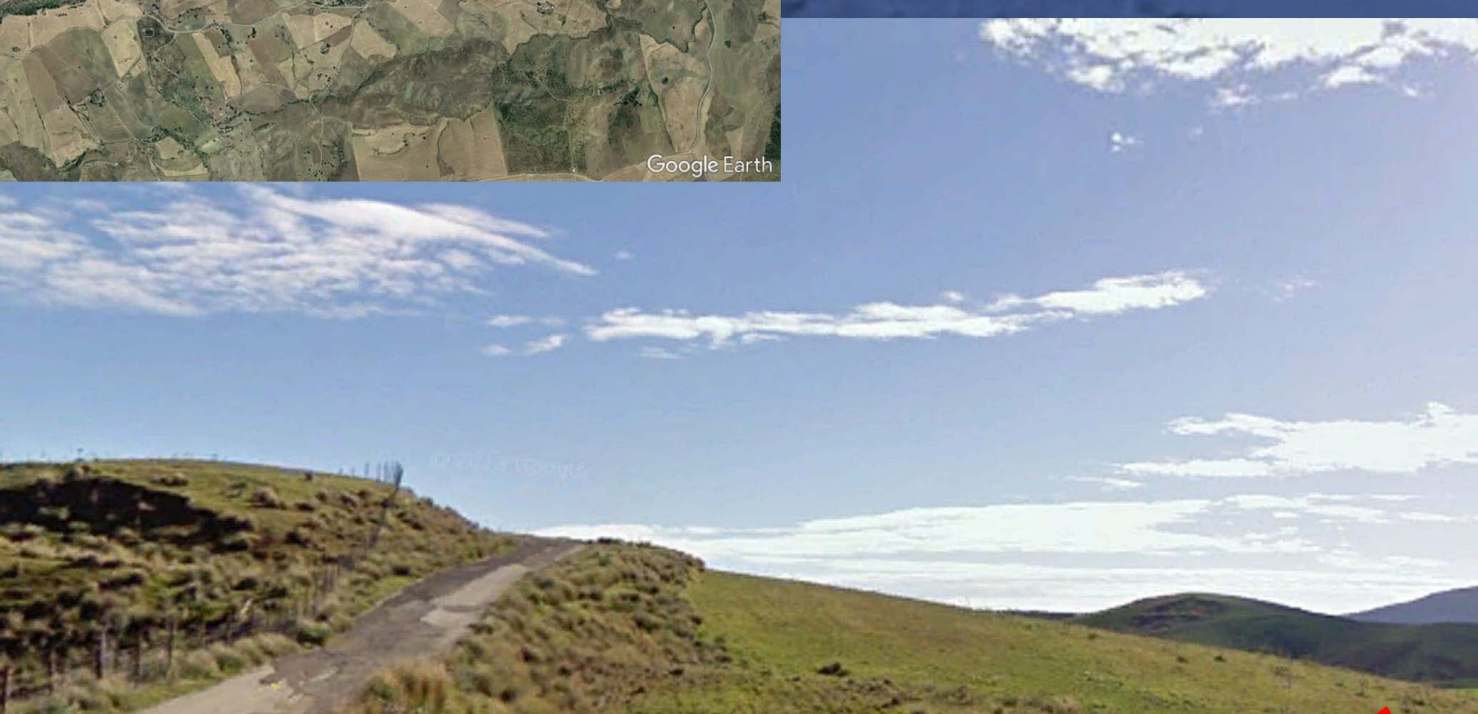

S.

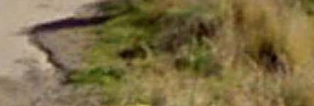

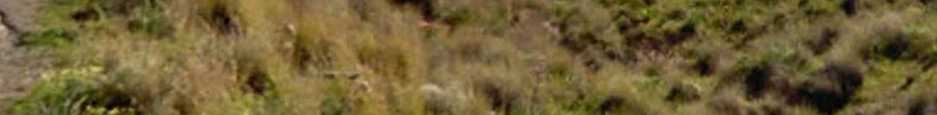

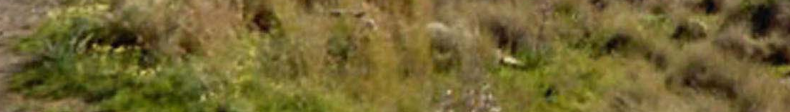

zatisto

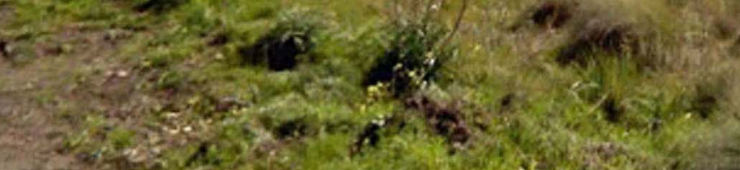

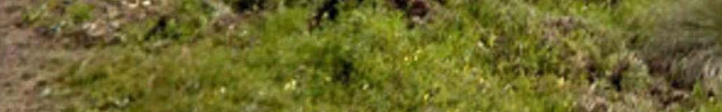

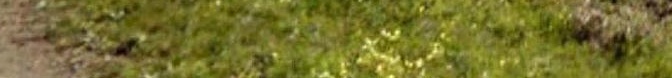

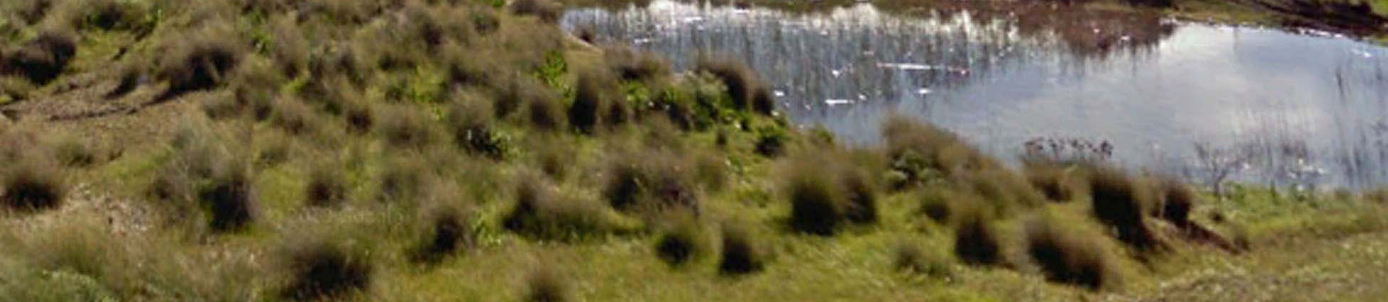

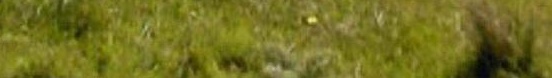




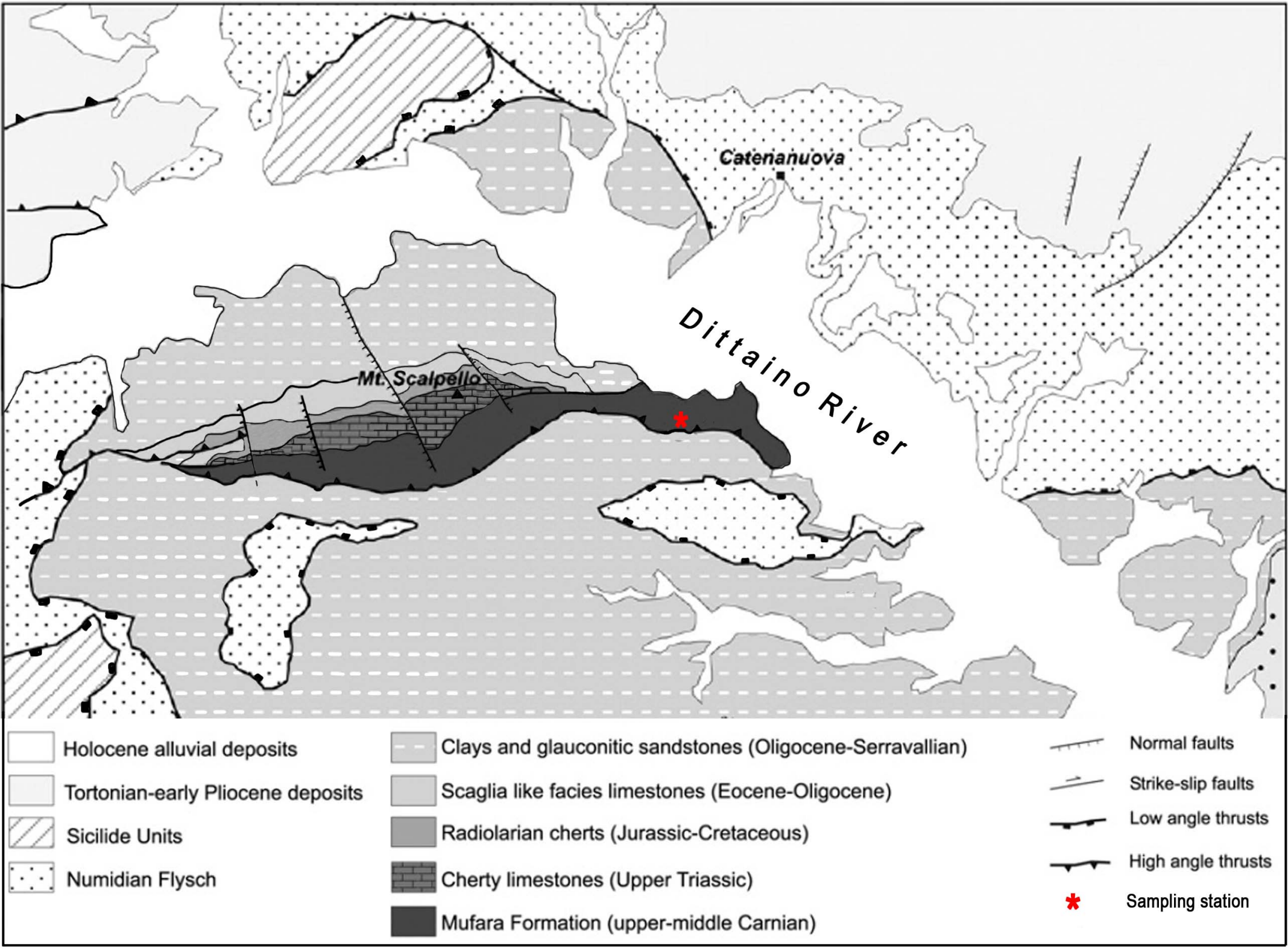




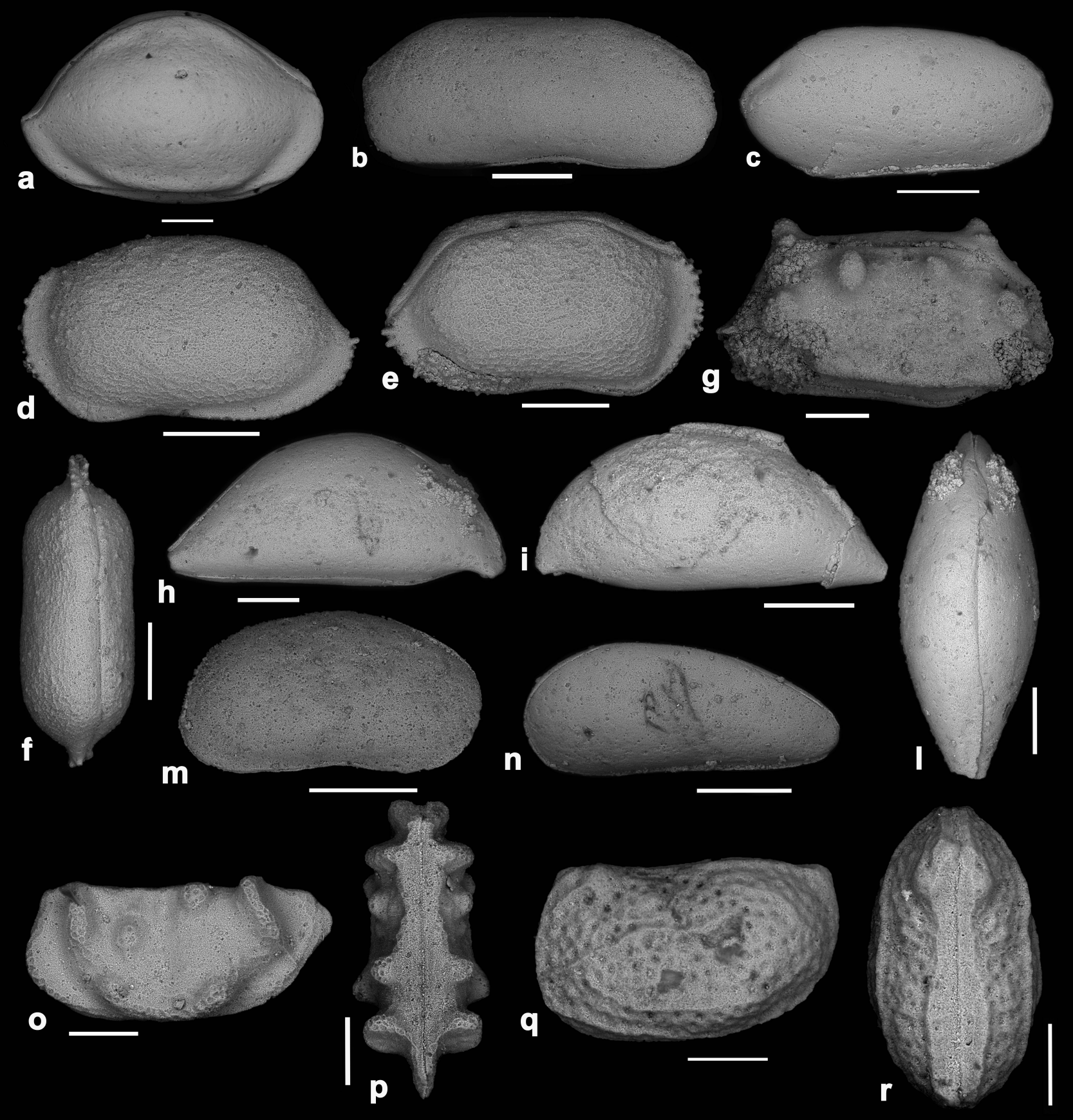

